\title{
PENGEMBANGAN APLIKASI MOBILE TRAVEL GUIDE PADA PROVINSI SUMATERA SELATAN
}

\author{
Usman Ependi*1, Febriyanti Panjaitan ${ }^{2}$, Firamon Syakti $^{3}$ \\ ${ }^{1,2,3}$ Fakultas Ilmu Komputer, Universitas Bina Darma \\ Email: ${ }^{1}$ u.ependi@binadarm.ac.id, ${ }^{2}$ febriyanti_panjaitan@binadarma.ac.id, ${ }^{3}$ firmaon.syakti@binadarma.ac.id \\ *Penulis Korespondensi
}

(Naskah masuk: 20 Juni 2019, diterima untuk diterbitkan: 27 April 2020)

\begin{abstract}
Abstrak
Sektor pariwisata adalah komponen penting bagi sebuah negara dalam meningkatkan pendapatan negara. Dalam mengelolah sektor pariwisata salah satu faktor penting adalah penyediaan informasi terutama petunjuk perjalanan wisata terutama tujuan wisata dan hal yang terkaitan dengannya. Di Indonesia terutama di Provinsi Sumatra Selatan berbagai upaya telah dilakukan pemerintah dalam menyediakan informasi pariwisata diantaranya melalui iklan, koran dan televisi. Namun penggunaan media tersebut belum cukup efektif yang dibebabkan tidak dapat diakses langsung (real time) oleh wisatawan. Selain itu, media ini memiliki keterbatasan dalam menjangkau wisatawan karena kegiatan pariwisata yang dilakukan wisatawan. Untuk itu didalam penelitian ini dilakukan pengembangan aplikasi mobile yang dikhususkan untuk penyediaan informasi wisata yang ada di Provinsi Sumatra Selatan. Proses pengembangan aplikasi mobile yang digunakan adalah Mobile D, dengan tahapan explore, initialize, productionize, stabilize, system test dan fix. Informasi yang tersedia didalam aplikasi ini terdiri dari tujuan wisata dan hal yang terkaitan dengannya. Dengan demikian wisatawan dapat dengan mudah mencari informasi berkaitan dengan tujuan wisata dan yang terkait dengan pariwisata yang ada di Provinsi Sumatra Selatan yang dibuktikan dengan hasil pengujian dengan istrumen heuristic evaluation yang mendapatkan nilai rerata 0.2 dan system usability scale mendapatkan nilai rerata 84.75 . Nilai pengujian menunjukkan bawah aplikasi mobile yang dihasilkan tidak memiliki masalah usability dan dapat diterima oleh pengguna. Sesuai kondisi tersebut diharapkan wisatawan dapat dengan mudah dalam mencari informasi tentang parwisata dan hal terkait dengannya melalui perangkat smartphone yang mereka miliki.
\end{abstract}

Kata kunci: Aplikasi Mobile, Pengembangan, Travel Guide, Usability

\section{MOBILE APPLICATION DEVELOPMENT FOR TRAVELLING GUIDE IN SOUTH SUMATRA}

\begin{abstract}
The tourism sector is an important component for a country to increase its income. In managing the tourism sector, an important factor is to provide information on travel guides that include tourism destinations and matters related to travel. In Indonesia, especially in the South Sumatra Province, various efforts have been made to provide information to travelers, such as through advertising, pamphlets, newspapers, and television. However, these media are not effective because travelers cannot access them in real-time. Besides, these media have limitations in reaching tourists due to tourism activities. For this reason, in the research presented in this paper, the development of the mobile application as a tourism information media in the South Sumatra Province was carried out. The process of developing a mobile application used is Mobile D, with stages of exploring, initialize, production, stabilize, system test, and fix. The information available in this application consists of tourism destinations and matters related to travel. Therefore, travelers can easily search for a tourism destination and everything related to tourism, especially in South Sumatra Province based on testing results using heuristic evaluation that got average score 0.2 and using system usability scale that got average score 84.75. From the testing result of mobile application, the mobile application does not have usability problems and can be accepted by the user. According to these conditions, travelers are expected to easily find information about tourism and related matters through their smartphone devices.
\end{abstract}

Keywords: Mobile Application, Development, Traveling Guide, Usability 


\section{PENDAHULUAN}

Pariwisata merupakan aktivitas perjalanan yang dilakukan dengan maksud rekreasi dan berlibur untuk menghilangkan kepenatan, mengusir bosan dan menambah pengalaman baru. Merencanakan perjalanan wisata biasanya berkaitan erat dengan tujuan tempat wisata, tujuan tempat wisata yang menyenangkan, memuaskan dan memberikan hiburan menjadi prioritas dalam melakukan perjalanan wisata. Perjalanan wisata bagi sebagian besar orang merupakan perjalanan untuk mencari pengalaman baru dengan tujuan tempat yang baru pula. Tidak mudah memperoleh informasi yang lengkap, akurat dan ter-update tentang tujuan objek wisata yang akan dikunjungi. Hal-hal yang perlu diperhatikan selama berada didaerah tujuan objek wisata adalah melihat kebenaran informasi mengenai akomodasi, sarana dan prasarana di tempat tujuan wisata. Dalam melakukan perjalanan wisata kebutuhan akomodasi dan transportasi sangat penting, karena berpengaruh pada kepuasan wisatawan selama melakukan wisata. (Chatzigeorgiou and Simeli, 2017). Kebutuhan akomodasi dan sarana prasarana perjalanan wisata diantaranya hotel, restoran, objek wisata, sistem transportasi, dan penjualan suvenir (Ivkov-Džigurski et al., 2008). Provinsi Sumatera Selatan adalah Salah satu provinsi di Indonesia, sejak dahulu terkenal dengan pusat Kerajaan Sriwijaya dan memiliki beberapa obyek wisata unggulan dan favorit di Indonesia. Pada saat ini Provinsi Sumatera Selatan sedang berusaha meningkatkan sektor pariwisata yang ditunjukkan dengan berdirinya perguruan tinggi dibidang pariwisata (Indonesia, 2016). Dalam mempromosikan pariwisata pemerintah Provinsi Sumatera Selatan telah melakukan berbagai hal, di antaranya menjadi tuan rumah pada event nasional dan internasional. Adapun dampak dari promosi yang telah dilakukan yaitu adanya peningkatan jumlah kunjungan wisatawan baik wisatawan domestik maupun internasional (RI, 2018).

Meningkatnya kunjungan wisatawan berdampak pada penyediaan informasi tujuan objek wisata dan semua yang terkait dengan perjalanan wisata. Pada saat ini informasi pariwisata hanya tersedia pada website pemerintah melalui dinas pariwisata provinsi saja. Informasi tersebut masih kurang memadai khususnya berkaitan dengan tujuan objek wisata dan akomodasi/sarana prasarana perjalanan wisata. Kurangnya informasi tersebut akan mengakibatkan turunnya minat wisatawan untuk berkunjung ke Provinsi Sumatera Selatan. Usaha yang telah dilakukan oleh pemerintah Provinsi Sumatera Selatan belum secara maksimal. Untuk itu perlu dibangun sebuah alat bantu sebagai sarana dalam memberikan informasi pariwisata berupa panduan/petunjuk perjalanan wisata.

Dalam memberikan informasi panduan perjalanan wisata banyak cara yang telah dilakukan pemerintah Provinsi Sumatera Selatan seperti iklan, pamflet, koran dan televisi, namun penggunaan media tersebut belum atau tidak dapat diakses oleh wisatawan secara maksimal karena tidak selalu tersedia setiap saat. Selain itu, media ini memiliki keterbatasan dalam menjangkau wisatawan karena kegiatan pariwisata yang dilakukan wisatawan. Untuk itu agar penyediaan informasi perjalanan wisata menjadi efektif maka dapat dilakukan menggunakan mobile application melaui smartphone. Pengunaan perangkat mobile pada smartphone disebabkan saat ini semua orang termasuk wisatawan telah menggunakannya dalam kehidupan sehari-hari. Dengan maksud agar dapat selalu diakses dan dilihat kapanpun dan dimanapun wisatawan berada. Penggunaan mobile application sebagai solusi pemberian informasi perjalanan wisata disebabkan beberapa alasan diantaranya: (1) Pengguna internet melalui mobile device di Indonesia baik wisatawan nasional maupun wisatawan internasional mencapai $83,44 \%$, (2) Pencarian informasi melalui mobile device mencapai $87,13 \%$, (3) Peningkatan pengguna internet terutama melalui mobile device mencapai $37,12 \%$ per tahun dan (4) Pengaksesan internet melalui mobile device setiap harinya mencapai 65,98\% (APJII, 2018). Usia tertinggi pengguna internet melalui mobile device adalah 25 sampai dengan 34 tahun, dan pada usia tersebut juga perjalanan wisata sering dilakukan (Antoun, 2015).

Kajian berkaitan dengan pariwisa telah banyak dilakukan diantanya yaitu: (1) SIG objek wisata di Kota Kupang. Didalam kajian tersebut dibuat sebuah sistem informasi geografis untuk menampilkan objek wisata berbasis web, di dalam sistem informasi yang dihasilkan tidak memiliki kategori informasi yang dapat memudahkan pengguna dalam mencari informasi (Tumimomor et al., 2013). (2) SIG objek wisata Edukasi di Jakarta. Di dalam kajian ini dibuat sebuah SIG berbasis mobile untuk menampilkan infomrasi tempat wisata edukasi (Putra, 2017). (3) SIG pemetaan wisata religi, di dalam kajian ini fokus yang dicapai hanya untuk menampilkan lokasi-lokasi wisata religi saja (Vinandari et al., 2019). Berdasarkan uraian tersebut dalam penelitian ini dirumuskan permasalahan yaitu bagaimana pengembangan mobile application yang memiliki fitur kategori wisata dan hal yang terkai dengan wisata. Dimana tujuan utama pengembangan mobile application ini memberikan informasi tujuan wisata dan berbagai hal yang terkait dengan perjalanan wisata. Diharapkan hasil pengembaangan membantu wisatawan dalam melakukan perjalanan dan pada akhirnya meningkatkan kepuasan layanan wisata yang ada pada Provinsi Sumatera Selatan.

\section{METODE PENELITIAN}

Dalam melakukan penelitian ini metode yang digunakan adalah metode deskriptif. Metode 
deskriptif merupakan metode yang digunakan untuk menjelaskan dan menjabarkan keadaan atau fenomena sesuai prosedur ilmiah (Ependi, 2018). Sedangkan metode pengembangan mobile application menggunakan Mobile D. Terdapat beberapa macam motode pengembangan khusus untuk mobile diantaranya adalah MASAM, SLeSS dan Mobile D. MASAM merupakan model pengembangan yang dilakukan berdasarkan agile framework namun langkah-langkah pengerjaan dan implementasi sangat mirip dengan Mobile D (Rahimian and Ramsin, 2008). Metode ini pertama kali ditemukan pada tahun 2008 dengan proses pengerjaan yaitu poreparation, embodiment, development, dan commercialization (Jeong et al., 2008) dan cocok untuk pengembangan pada perusahaan kecil. SLeSS merupakan model pengembangan penyempurnaan dari SCRUM dan bagian dari agile, model ini memiliki lima langkah pengerjaan yaitu definition, measurement, analysis, improvement and control (da Cunha et al., 2011). SLeSS pertama kali ditemukan pada tahun 2011 dan penggunaannya khusus untuk pengembangan embedded software. Sedangkan Mobile D merupakan salah satu metode pelopor dalam bidang proses pengembangan mobile application. Metode Mobile D dapat dilakukan secara tim dengan jumlah anggota kurang dari 10 orang dan waktu pengerjaan relatif singkat kurang dari sepuluh minggu (Mahmud and Abdullah, 2015). Mobile D pertama kali muncul pada tahun 2004 merupakan metode pengembangan yang mengedepankan kecepatan baik dalam proses pengembangan maupun perubahan (Abdalhamid and Mishra, 2017) yang memiliki lima tahapan: explore, initialize, productionize, stabilize, system test dan fix seperti yang terlihat pada Gambar 1.

Untuk itu dalam menyelesaikan penelitian ini digunakan Mobile D sebagai proses pengembangan perangkat lunak. Penggunaan Mobile D disebabkan karena model ini tidak membutuhkan jumlah tim yang banyak dan waktu pengerjaan lebih singkat. Selain itu juga sasaran produk yang dihasilkan tidak spesifik seperti pada model pengembangan MASAM dan SLeSS. Namun ketiga model tersebut mengedepankan prinsip agile (Abdalhamid and Mishra, 2017). Prinsip-prinsip tersebut antara lain adalah (1) kepuasan pelanggan menjadi prioritas (Ependi, 2017a), (2) selalu siap dengan perubahan (3) penyajian hasil pengembangan secara berkala, (4) melakukan pekerjaan sebagai tim atau bersama (Ferdiana et al., 2011), (5) memberikan semangat anggota tim, (6) pengumpulan informasi yang relevan dengan pekerjaan, (7) mengedepankan pekerjaan pengembangan, (8) menjaga hubungan dengan stakeholder terutama pihak sponsor (Alqudah and Razali, 2016), (9) pekerjaan teknis menjadi prioritas, (10) menyederhanakan pekerjaan, (11) menggunakann tim sendiri dalam membuat arsitektur, analisis kebutuhan, dan perancangan, dan (12) bekerja dengan efektif dan berkala (Ibrahim, 2012).

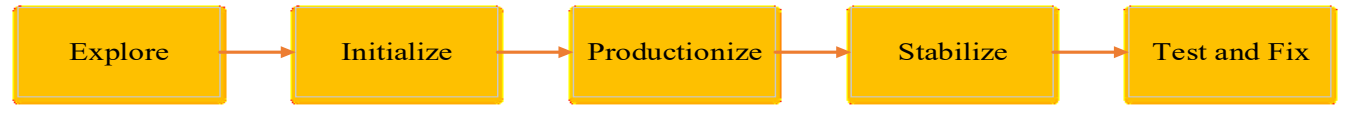

Gambar 1. Proses pengembangan Mobile D (Flora and Chande, 2013)

Pada penelitian ini proses pengembangan mobile application untuk panduan wisata dilakukan sesuai dengan Mobile D. Alur proses pekerjaan penelitian seperti pada Gambar 1 dapat diketahui yaitu: tahap pertama explorer, tahapan ini dilakukan permulaan pengembangan dan penentuan pengguna aplikasi. Dalam penelitian ini terdapat beberapa jenis pengguna aplikasi yang menjadi target yaitu dinas pariwisata, masyarakat Sumatera Selatan dan wisatawan. Sebelum memulai pengembangan aplikasi dilakukan wawancara kepada stakeholder terutama kepada pihak pemerintah yang diwakili oleh dinas pariwisata dan Dinas Kominfo Provinsi Sumatera Selatan. Wawancara dilakukan untuk mendapatkan informasi seputar keinginan mereka dan kebutuhan yang berkaitan dengan aplikasi yang akan dibuat. Tahap kedua initialize, tahapan ini dilakukan pemilihan bentuk atau fitur apa saja yang akan dibuat pada aplikasi. Pemilihan fitur tersebut dibuat berdasarkan jenis pengguna yang telah ditentukan pada fase explore. Tahap ketiga productionize, tahapan ini dilakukan pemodelan atau pembentukan alur proses dan desain database. Alur proses aplikasi digambarkan dalam bentuk proses bisnis diagram dan diterjemahkan dengan notasi arsitektur diagram aplikasi, sedangkan pembentukan database digambarkan dalam entity relationship diagram. Tahap keempat dan kelima stabilizie dan test \& fix merupakan tahapan pembenahan dan pengujian aplikasi yang dilakukan terus-menerus hingga aplikasi dianggap sempurna

\section{HASIL DAN PEMBAHASAN}

Hasil penelitian pengembangan mobile application sebagai alat bantu petunjuk perjalanan pada Provinsi Sumatera Selatan dapat dijelaskan sebagai berikut:

\subsection{Arsitektur Aplikasi}

Arsitektur aplikasi digunakan untuk menggambarkan kebutuhan fungsi bisnis dari aplikasi. Arsitektur aplikasi berkaitan erat dengan data dan pengguna yang melekat pada aplikasi biasanya dapat digambarkan secara logikal dan fisikal (Yunis and Surendro, 2009). Arsitektur 
aplikasi yang digambarkan dalam pengembangan mobile application travel guide pada provinsi Sumatra Selatan ini menggunakan fisikal seperti yang diperlihatkan pada Gambar 2. Arsitektur aplikasi seperti pada gambar 2 terdapat tiga jenis pengguna yaitu South Sumatera Society, Tourism Department (Regencies/Cities) dan Traveller. Untuk itu dapat dijelaskan aktivitas untuk masing-masing jenis pengguna seperti berikut ini:

1. South Sumatra Society: melakukan penambahan informasi yang terkait dengan perjalanan wisata yang ada pada Provinsi Sumatera Selatan. Penambahan data tersebut dilakukan secara real time karena aplikasi travel guide membaca posisi GPS pengguna. Dalam melakukan penambahan data pengguna diminta untuk memilih kabupaten/kota, kategori tempat, dan poto lokasi tempat. Dalam melakukan penambahan data terdapat dua belas kategori yaitu sport, transportation, hotel, store, restaurant, handicraft, tourism destination, gas station, hospital, police station, government office dan education.

2. Traveller: melakukan pencarian tujuan wisata dan hal terkait dengan pariwisata yang ada di Provinsi Sumatera Selatan.
Pencarian tujuan wisata dapat dilakukan dengan memilih kabupaten/kota dan dilanjutkan denan memilih kategori tempat yang akan dilihat. Kategori tersebut meliputi sport, transportation, hotel, store, restaurant, handicraft, tourism destination, gas station, hospital, police station, government office dan education. Setelah mendapatkan tujuan maka traveller dapat melihat detail informasi seperti nama tempat, deskripsi, gambar dan menu interaktif. Menu yang ada pada detail tempat meliputi rate, rute, dan update. Rate digunakan untuk memberikan rating tempat dengan login akun facebook, rute melihat rute perjalanan, dan update melakukan perbaikan posisi tempat jika dianggap kurang tepat. Selain itu juga traveller dapat menambah gambar sebagai galeri pada lokasi yang dia kunjungi.

3. Tourism Department (Regencies/cities): melakukan validasi data yang dimasukkan oleh South Sumtera Society dan verifikasi gambar yang di-upload oleh traveller.

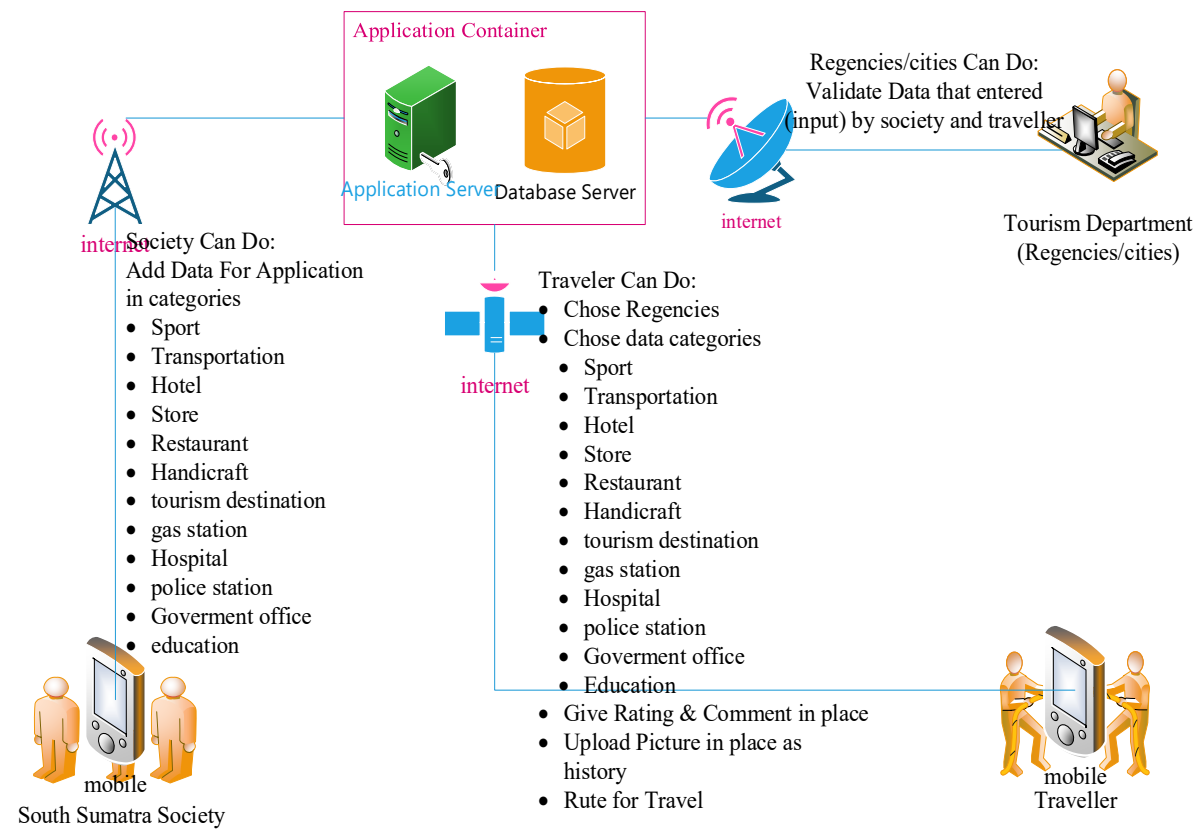

Gambar 2. Arsitektur aplikasi

- Tujuan dari nama menu menggunakan kabupaten/kota agar traveller dapat dengan mudah dalam mencari informasi wisata pada masingmasing kabupaten/kota yang ada di Provinsi Sumatera Selatan seperti yang diperlihatkan pada Gambar 3. Untuk melihat mobile application travel guide Provinsi Sumatra Selatan ini secara menyeluruh dapat dilihat pada arsitektur menu aplikasi. Arsitektur menu aplikasi merupakan ilustrasi fitur aplikasi seperti yang diperlihatkan pada Gambar 4.

Untuk memudahkan wisatawan dalam melakukan pencarian informasi berkaitan dengan informasi wisata di Provinsi Sumatera Selatan maka informasi tersebut dikelompokkan berdasarkan kategori. Kategori informasi dapat dilihat oleh wisatawan ketika mereka telah memilih kabupaten/kota yang ada di home screen aplikasi. Untuk itu dapat 
diketahui makna dari menu dan icon yang ada pada kategori informasi seperti yang dijelaskan pada Tabel 1.

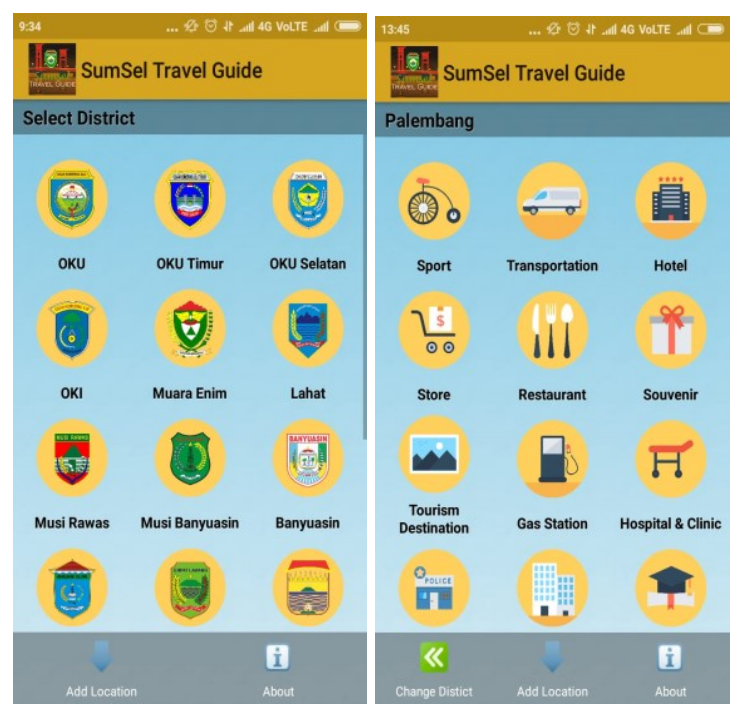

Gambar 3 Home screen dan place categories

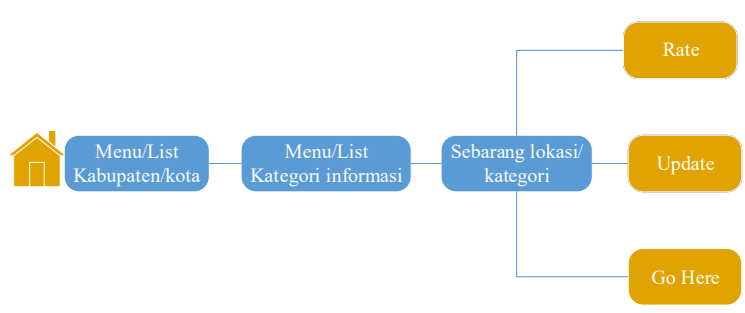

Gambar 4 Arsitektur menu aplikasi

Dengan adanya kategori informasi seperti pada Tabel 1 maka wisatawan dapat melakukan pencarian informasi perjalanan wisata di Provinsi Sumatera Selatan dengan mudah dan cepat. Kemudahan pencarian tersebut disebabkan informasi yang ditampilkan telah dikelompokkan sesuai dengan jenis informasi yang dibutuhkan ketika seseorang melakukan perjalanan wisata. Di dalam aplikasi ini juga telah tersedia berbagai macam jenis informasi dan interaksi bagi pengguna di antaranya profil kabupaten/kota yang ada di Provinsi Sumatra Selatan, penambahan objek sesuai kategori, penambahan gambar objek oleh traveller, dan pemberian saran atau komentar pada objek. Untuk melihat informasi sesuai kategori misal tujuan tempat wisata maka traveller dapat langsung ke menu tourism destination maka semua tujuan tempat wisata dan detail informasi akan ditampilkan seperti pada Gambar 5.

Selain dapat melakukan pencarian dan melihat detail informasi pada objek yang diperlihatkan pada Gambar 5 maka wisatawan juga dapat melakukan pemberian rating, update posisi lokasi objek dan melihat rute perjalanan. Untuk melakukan pemberian rating maka wisatawan harus menggunakan akun facebook sebagai anti spam seperti yang diperlihatkan pada Gambar 6 .
Pemberian rating digunakan sebagai referensi bagi wisatawan dalam menentukan tujuan wisata atau hal yang terkait dengan tujuan wisata. Selain itu juga wisatawan dapat melihat rute perjalanan, wisatawan dapat langsung go here maka otomatis rute perjalanan akan ditampilkan seperti yang diperlihatkan pada Gambar 6.

Tabel 1. Kategori Tempat

\begin{tabular}{ll}
\hline Menu dan Pointer & \multicolumn{1}{c}{ Deskripsi } \\
\hline & $\begin{array}{l}\text { Sport: } \\
\text { Kategori sport berisikan informasi } \\
\text { tempat-tempat olahraga seperti } \\
\text { lapangan olahraga, tempat joging dan } \\
\text { fasilitas olahraga lainnya. Informasi ini } \\
\text { disediakan untuk wisatawan jika ingin } \\
\text { melakukan olahraga. }\end{array}$
\end{tabular}

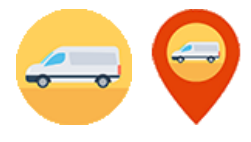

Transportation:

Kategori transportation berisikan informasi keberadaan pol taksi, halte bus, stasiun kereta, stasiun LRT dan bandara. Informasi transportasi yang ditampilkan hanya transportasi umum dan dapat digunakan oleh wisatawan jika akan melakukan perjalanan wisata.

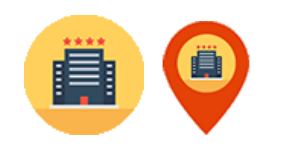

Hotel:

Kategori hotel berisikan informasi keberadaan hotel. Informasi hotel yang ditampilkan mulai dari hotel kelas melati sampai dengan hotel kelas berbintang. Informasi hotel dapat digunakan oleh wisatawan untuk menginap dan melihat hotel di sekitar objek wisata yang akan dikunjungi.

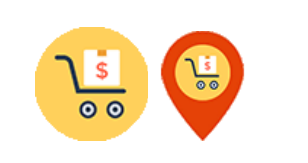

Store:

Kategori store berisikan informasi keberadaan mini market, super market, dan mall. Selain juga pada kategori ini terdapat informasi keberadaan tokotoko yang dimiliki masyarakat secara perorangan. Informasi ini dapat digunakan oleh wisatawan jika ingin berbelanja keperluan selama perjalanan.

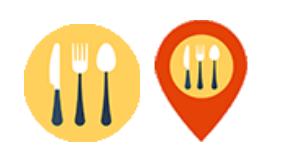

\section{Restaurant:}

Kategori restaurant berisikan informasi keberadaan restoran baik bersifat tradisional restoran maupun restoran waralaba. Informasi ini dapat digunakan oleh wisatawan untuk menikmati makanan selama perjalanan sekaligus promosi kuliner bagi Provinsi Sumatera Selatan.

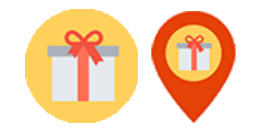

\section{Souvenir:}

Kategori souvenir berisikan informasi keberadaan tempat-tempat penjualan suvenir. Informasi yang diberikan pada kategori ini khusus untuk informasi tempat penjualan suvenir. Informasi pada kategori ini dapat digunakan wisatawan jika ingin membeli suvenir khas daerah Provinsi Sumatera Selatan. 


\begin{tabular}{|c|c|}
\hline Menu dan Pointer & Deskripsi \\
\hline & $\begin{array}{l}\text { Tourism Destination: } \\
\text { Kategori tourism destination berisikan } \\
\text { informasi objek wisata yang dapat } \\
\text { dikunjungi oleh wisatawan. Informasi } \\
\text { objek wisata yang ditampilkan dapat } \\
\text { digunakan oleh wisatawan dalam } \\
\text { menentukan tujuan wisata yang akan } \\
\text { dilakukan. }\end{array}$ \\
\hline & $\begin{array}{l}\text { Gas Station: } \\
\text { Kategori gas station berisikan informasi } \\
\text { tempat pengisian bahan bakar } \\
\text { kendaraan. Informasi ini dapat } \\
\text { digunakan oleh wisatawan untuk } \\
\text { mengisi bahan bakar jika mereka } \\
\text { menyewa kendaraan dalam melakukan } \\
\text { wisata. }\end{array}$ \\
\hline & $\begin{array}{l}\text { Hospital \& Clinic: } \\
\text { Kategori hospital \& clinic berisikan } \\
\text { informasi rumah sakit, klinik, praktik } \\
\text { dokter dan puskesmas. Informasi ini } \\
\text { dapat digunakan oleh wisatawan jika } \\
\text { jatuh sakit atau dalam keadaan darurat. }\end{array}$ \\
\hline & $\begin{array}{l}\text { Police Station: } \\
\text { Kategori police station berisikan } \\
\text { informasi keberadaan kantor polisi dan } \\
\text { pos polisi. Informasi ini dapat } \\
\text { digunakan oleh wisatawan jika } \\
\text { mendapatkan masalah keamanan } \\
\text { ataupun kehilangan paspor untuk } \\
\text { memberikan laporan agar dapat } \\
\text { ditindak lanjuti. }\end{array}$ \\
\hline & $\begin{array}{l}\text { Government Office: } \\
\text { Kategori government office berisikan } \\
\text { informasi keberadaan informasi kantor- } \\
\text { kantor pemerintah yang ada di Provinsi } \\
\text { Sumatera Selatan terutama kantor dinas } \\
\text { pariwisata maupun imigrasi. Informasi } \\
\text { ini dapat digunakan oleh wisatawan jika } \\
\text { ingin mendapatkan bantuan dan layanan } \\
\text { dari pemerintah. }\end{array}$ \\
\hline & $\begin{array}{l}\text { Education: } \\
\text { Kategori education berisikan informasi } \\
\text { keberadaan lembaga pendidikan } \\
\text { terutama pendidikan tinggi. Informasi } \\
\text { ini dapat digunakan oleh wisatawan jika } \\
\text { ingin melihat secara akademik } \\
\text { perkembangan budaya yang ada di } \\
\text { Provinsi Sumatera Selatan. }\end{array}$ \\
\hline
\end{tabular}

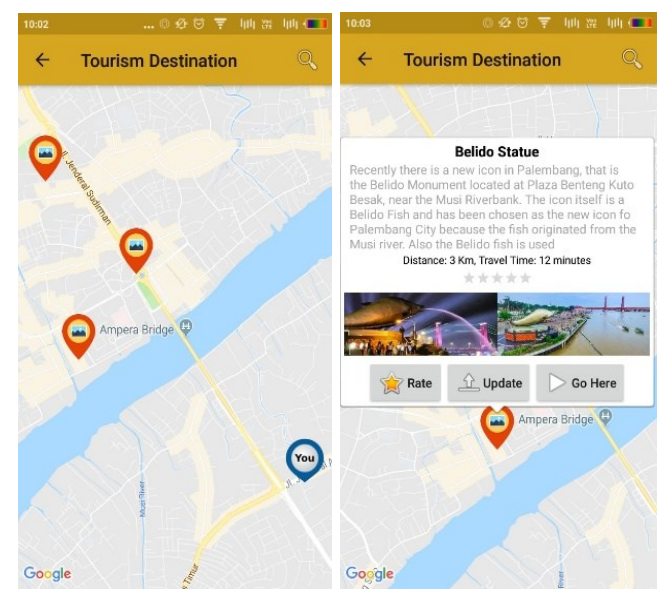

Gambar 5. Kategori dan detail informasi lokasi

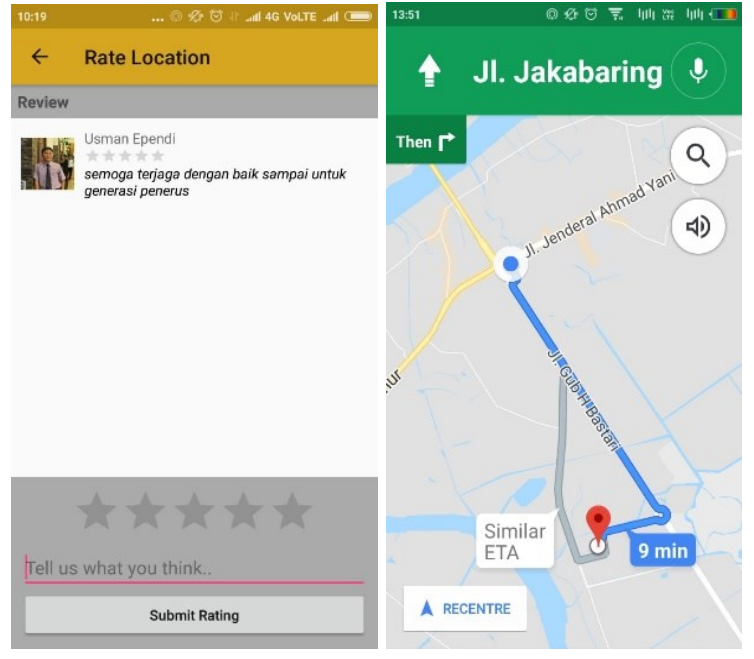

Gambar 6. Kategori dan detail informasi lokasi

\subsection{Pengujian Aplikasi}

Pengujian aplikasi merupakan proses validasi dan verifikasi untuk memenuhi standar usability (Pressman, 2009). Untuk itu pengujian usability digunakan untuk melihat seberapa mudah aplikasi ketika digunakan oleh pengguna., yang dilihat dari lima aspek yaitu: (1) learnability, (2) efficiency, (3) memorability, (4) errors and (5) satisfaction (Abdellatif et al., 2018). Teknik pengujian usability yang biasaya digunakan adalah heuristic evaluation (HE) dan System Usability Scale (SUS). Pengujian HE yang memiliki sepuluh instrumen (Nielsen, 1994) seperti yang diperlihatkan pada Tabel 2. Dalam melakukan pengujian usability dengan teknik heuristic evaluation melibatkan ahli dalam proses pengerjaannya. Ahli yang terlibat tiga sampai dengan lima ahli (Desurvire et al., 2004). Skor dalam pengujian terdiri dari 0 sampai dengan 4,0 menunjukkan bahwa aplikasi tidak ada masalah berkaitan dengan usability, 1 menunjukkan aplikasi memiliki masalah kosmetik, 2 menunjukkan aplikasi memiliki masalah minor, 3 menunjukkan aplikasi memiliki masalah major, dan 4 menunjukkan bahwa aplikasi harus dilakukan desain ulang (Nielsen, 1992). Selain itu juga pengujian dengan instrumen heuristic evaluation memiliki keuntungan yaitu: (1) lebih cepat mendapatkan feedback dan lebih murah, (2) dapat dilakukan bersamaan dengan teknik pengujian lain (Nielsen, 1992), (3) pendeteksian maslaah lebih awal, dan (4) dapat dilakukan untuk pengujian perangkat keras maupun perangakt lunak (aplikasi mobile, dan web aplikasi) (Ependi, 2017b).

Pengujian dengan teknik SUS merupakan pengujian usability yang melibatkan pengguna akhir aplikasi. Untuk melakukan pengujian SUS pengguna yang terlibat dapat mengikuti aturan dari HE (Ependi et al., 2019). Pengujian SUS dapat dilakukan dengan lima (5) responden, sepuluh (10) responden atau bahkan lebih (Pudjoatmodjo and Wijaya, 2016). Untuk menentukan jumlah responden tergantung dari perspektif peneliti yang melakukan 
proses pengujian. Untuk melakukan pengujian dengan teknik SUS terdapat sepuluh (10) instrumen dengan lima (5) pilihan jawaban yang digunakan seperti yang diperlihatkan pada Tabel 3.

\begin{tabular}{|c|c|}
\hline Instrumen & Deskripsi \\
\hline $\begin{array}{l}\text { Visibility } \\
\text { system status }\end{array}$ & $\begin{array}{l}\text { untuk menilai apakah aplikasi dapat } \\
\text { memberikan informasi kepada pengguna } \\
\text { tentang proses yang sedang berjalan dan } \\
\text { memberikan informasi yang jelas. }\end{array}$ \\
\hline $\begin{array}{l}\text { Match between } \\
\text { system and the } \\
\text { real world }\end{array}$ & $\begin{array}{l}\text { untuk menilai apakah suatu aplikasi } \\
\text { menggunakan bahasa tidak asing bagi } \\
\text { pengguna termasuk kata-kata, frasa dan } \\
\text { konsep. }\end{array}$ \\
\hline $\begin{array}{l}\text { User control } \\
\text { and freedom }\end{array}$ & $\begin{array}{l}\text { untuk menilai apakah pengguna dapat } \\
\text { secara bebas menggunakan aplikasi seperti } \\
\text { tidak adanya proses yang diterapkan pada } \\
\text { pengguna dan dapat melakukan undo dan } \\
\text { redo. }\end{array}$ \\
\hline $\begin{array}{l}\text { Consistency and } \\
\text { standards }\end{array}$ & $\begin{array}{l}\text { untuk menilai apakah dalam menggunakan } \\
\text { aplikasi pengguna tidak menemukan kata- } \\
\text { kata dan ikon yang mendua yang dapat } \\
\text { membuat pengguna melakukan kesalahan. }\end{array}$ \\
\hline $\begin{array}{l}\text { Error } \\
\text { prevention }\end{array}$ & $\begin{array}{l}\text { untuk menilai bagaimana aplikasi } \\
\text { menangani atau mencegah kesalahan yang } \\
\text { dapat dilakukan oleh pengguna. }\end{array}$ \\
\hline $\begin{array}{l}\text { Recognition } \\
\text { rather than } \\
\text { recall }\end{array}$ & $\begin{array}{l}\text { untuk menilai apakah aplikasi dapat } \\
\text { meminimalkan memori pengguna dalam } \\
\text { mengingat sesuatu seperti makna gambar, } \\
\text { pilihan, dan informasi lainnya. }\end{array}$ \\
\hline $\begin{array}{l}\text { Flexibility and } \\
\text { efficiency of use }\end{array}$ & $\begin{array}{l}\text { untuk menilai apakah aplikasi yang dibuat } \\
\text { dapat membuat aktivitas (kerja) lebih cepat } \\
\text { dan apakah aplikasi menyediakan jalan } \\
\text { pintas dibandingkan dengan metode } \\
\text { konvensional. }\end{array}$ \\
\hline $\begin{array}{l}\text { Aesthetic and } \\
\text { minimalist } \\
\text { design }\end{array}$ & $\begin{array}{l}\text { untuk menilai apakah aplikasi yang dibuat } \\
\text { memiliki bagian / menu / informasi yang } \\
\text { tidak relevan dengan kebutuhan pengguna. }\end{array}$ \\
\hline $\begin{array}{l}\text { Help users } \\
\text { recognize, } \\
\text { diagnose, and } \\
\text { recover } \\
\text { from errors }\end{array}$ & $\begin{array}{l}\text { untuk menilai apakah suatu aplikasi dapat } \\
\text { menampilkan pesan kesalahan dan mudah } \\
\text { ditangani. }\end{array}$ \\
\hline $\begin{array}{l}\text { Help and } \\
\text { documentation }\end{array}$ & $\begin{array}{l}\text { untuk menilai apakah aplikasi yang dibuat } \\
\text { dapat dijalankan tanpa membaca } \\
\text { dokumentasi atau bantuan dan mudah untuk } \\
\text { menemukan informasi. }\end{array}$ \\
\hline
\end{tabular}

SUS memiliki Teknik perhitungan yang berbeda dengan HE. Perbedaan tersebut terletak pada nomor instrumen SUS yaitu nomor ganjil dan genap (Ependi et al., 2017). Dimana ketentuan perhitungan tersebut adalah:

a. Instrumen ganjil skala jawaban responden dikurangi dengan 1

b. Instrumen genap, 5 dikurangi skala jawaban responden.

c. Skala penilaian 0 - 4 (4 adalah jawaban terbaik).

d. Menjumlahkan jawaban responden dan dikali 2.5

e. Menentukan rerata jawaban untuk semua responden.
Tabel 3. Instrumen system usability scale “

\begin{tabular}{clc}
\multicolumn{4}{c}{ Pernyataan } & Skala \\
\hline No & \multicolumn{1}{c}{$\begin{array}{l}\text { I think that I would like to use this system } \\
\text { frequently }\end{array}$} & $1 \mathrm{~s} / \mathrm{d} 5$ \\
2 & $\begin{array}{l}\text { Ifound the system unnecessarily complex. } \\
\text { I thought the system was easy to use }\end{array}$ & $1 \mathrm{~s} / \mathrm{d} 5$ \\
& $\begin{array}{l}\text { I think that I would need the support of a } \\
\text { technical person to be able to use this } \\
\text { system. }\end{array}$ & $1 \mathrm{~s} / \mathrm{d} 5$ \\
5 & $\begin{array}{l}\text { Ifound the various functions in this system } \\
\text { were well integrated }\end{array}$ & $1 \mathrm{~s} / \mathrm{d} 5$ \\
6 & $\begin{array}{l}\text { I thought there was too much inconsistency } \\
\text { in this system }\end{array}$ & $1 \mathrm{~s} / \mathrm{d} 5$ \\
7 & $\begin{array}{l}\text { I would imagine that most people would } \\
\text { learn to use this system very quickly }\end{array}$ & $1 \mathrm{~s} / \mathrm{d} 5$ \\
9 & $\begin{array}{l}\text { Ifound the system very cumbersome to use } \\
\text { Ifelt very confident using the system }\end{array}$ & $1 \mathrm{~s} / \mathrm{d} 5$ \\
10 & $\begin{array}{l}\text { Ineeded to learn a lot of things before I } \\
\text { could get going with this system }\end{array}$ & $1 \mathrm{~s} / \mathrm{d} 5$ \\
\hline
\end{tabular}

Penentuan perhitungan SUS dapat dilakukan dengan tiga cara yaitu (1) acceptability, (2) grade scale, dan (3) adjective rating seperti yang diperlihatkan pada Gambar 7 (Tullis and Stetson, 2004). Acceptability memiliki tiga komponen yaitu (1) not acceptable, (2) marginal (rendah dan tinggi), dan (3) acceptable. Grade scale memilili lima tingkatan yaitu A, B, C, D dan F. sedangkan adjective rating memiliki enam tingkatan yaitu (1) worst imaginable, (2) poor, (3) ok, (4) good, (5) excelent dan (6) best imanginable (Bangor et al., 2009).

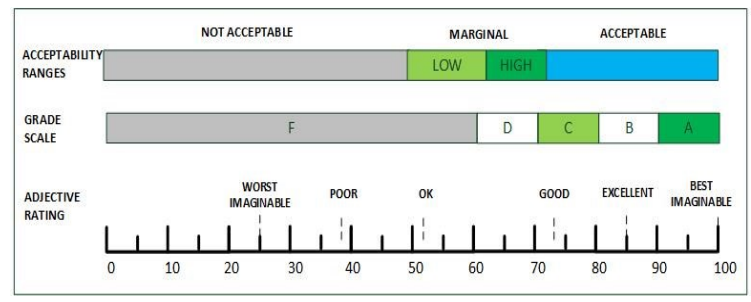

Gambar 7. Penentuan skor SUS

Berdasarkan instrumen HE seperti yang diperlihatkan pada Tabel 2 maka didapat hasil pengujian seperti yang diperlihatkan pada Tabel 5 . Dalam proses pengujian yang telah dilakukan melibatkan lima orang ahli (Silva et al., 2015) walaupun pada ada yang menyatakan dalam dilakukan kurang dari lima ahli (Lewis, 2014). Jumlah ahli yang terlibat dalam proses pengujian akan berdampak pada hasil pengujian. Semakin kecil jumlah ahli yang terlibat maka tingkat kesuksesan pengujian akan tinggi dan dapat lebih cepat menemukan kesalahan usability. Begitu juga sebaliknya semakin tinggi jumlah ahli yang terliibat kemungkinan kegagalan dan kesulitan dalam menemukan masalah usability (Nielsen, 1995). Pada Tabel 4 dapat dilihat profil singkat dari ahli yang terlibat dalam pengujian $\mathrm{HE}$. 
614 Jurnal Teknologi Informasi dan Ilmu Komputer (JTIIK), Vol. 7, No. 3, Juni 2020, hlm. 607-618

Tabel 4. Profil ahli dalam pengujian HE

\begin{tabular}{llll}
\hline No & Foto \\
\hline 1 & & \\
& & \\
& &
\end{tabular}

Darius Antoni, Ph.D (S3 RMIT University)

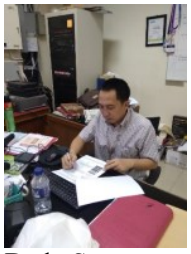

Dedy Syamsuar Ph.D (S3 Curtin University)

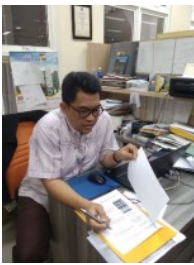

M. Izman Herdiansyah, Ph.D (S3 Curtin University)
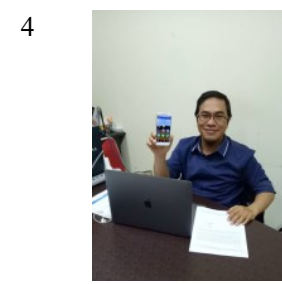

Tri Basuki Kurniawan, Ph.D (S3 UKM Malaysia)

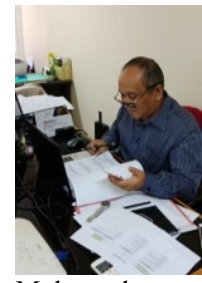

Muhamad Akbar, M.IT (S2 Curtin

University)

Keterangan

Merupakan ahli dalam bidang ilmu komputer terutama dapa e-government dan sistem informasi. Penelitian yang telah dilakukan diantaranya adalah "(1) the readiness of palm oil industry in enterprise resource planning, (2) critical factors of transparency and trust for evaluating e-government services for the poor, dan (3) adopsi website quality evaluation method (webqem) dan ISO 9126 untuk mengukur service quality pada ujian online".

Merupakan ahli dalam bidang ilmu komputer terutama pada software development dan network engineering. Penelitian yang telah dilakukan diantaranya adalah "(1) Understanding ipv6 resistance: a model of resistance among indonesian organizations, (2) structure community analysis on social network, dan (3) rencana strategis application portfolio pada Universitas Muhammadiyah Palembang dengan menggunakan metode ward and peppard".

Merupakan ahli dalam bidang ilmu komputer terutama bidang optimasi, software development, information system analysis. Peneltian yang telah dilakukan diantaranya adalah "(1) mathematical model of optimum composition on membrane fabrication parameters for treating batik Palembang wastewater, (2) IT strategy alignment in university using it balanced scorecard framework, dan (3) information systems architecture online learning in school with the Zachman framework".

Merupakan ahli dalam bidang ilmu komputer terutama dalam bidang software development, machine learning, data mining. Penelitian yang telah dilakukan diantaranya adalah “(1) An ant colony system for DNA sequence design based on thermodynamics, (2) Implementation of an ant colony system for DNA sequence optimization, dan (3) Function minimization in DNA sequence design based on continuous particle swarm optimization".

Merupakan ahli dalam bidang ilmu komputer terutama dalam bidang usability dan software development. Penelitian yang telah dilakukan diantaranya adalah “(1) IT Strategy Alignment in University Using IT Balanced Scorecard Framework, (2) Membangun Konsep E-Government Berdasarkan Faktor-Faktor Desain Grafis Di Indonesia Menggunakan Systematic Review, dan (3) Critical factors of transparency and trust for evaluating e-government services for the poor".
Tabel 5. Hasil pengujian dengan HE

\begin{tabular}{ccccccc}
\hline $\begin{array}{c}\text { Instrum } \\
\text { en }\end{array}$ & $\mathbf{A 1}$ & $\mathbf{A 2}$ & $\mathbf{A 3}$ & $\mathbf{A 4}$ & $\mathbf{A 5}$ & Total \\
\hline 1 & 0 & 1 & 0 & 0 & 0 & 0,2 \\
2 & 0 & 0 & 1 & 0 & 0 & 0,2 \\
3 & 1 & 0 & 0 & 1 & 0 & 0,4 \\
4 & 0 & 0 & 0 & 0 & 0 & 0,0 \\
5 & 1 & 1 & 0 & 0 & 0 & 0,4 \\
6 & 0 & 0 & 1 & 1 & 0 & 0,4 \\
7 & 0 & 0 & 1 & 0 & 0 & 0,2 \\
8 & 0 & 0 & 0 & 0 & 0 & 0,0 \\
9 & 1 & 0 & 0 & 0 & 0 & 0,2 \\
10 & 0 & 0 & 0 & 0 & 0 & 0,0 \\
Rerata/ & 0,3 & 0,2 & 0,3 & 0,2 & 0,0 & 0,2 \\
\hline ahli & & & & & & \\
\hline
\end{tabular}

Dari hasil pengujian HE seperti yang diperlihatkan pada Tabel 5 masing-masing instrumen mendapatkan nilai $0,0.2$ dan 0.4 . instrument yang mendapatkan nilai 0 terdapat pada tiga instrumen yaitu "(1) Consistency and standards (instrumen 2), (2) Aesthetic and minimalist design (instrumen 8), and (3) Help and documentation (instrumen 10)". Instrumen yang mendapatkan nilai 0.2 terdapat pada empat instrument yaitu "(1) Visibility of system status (instrumen 1), (2) Match between system and the real world (instrumen 2), (3) Flexibility and efficiency of use (instrumen 7), dan (4) Help users recognize, diagnose, and recover from errors (instrumen 9)". Sedangkan instrumen yang mendapatkan nilai 0.4 terdapat pada tiga instrumen yaitu: "(1) User control and freedom (instrumen 3), (2) Error prevention (instrumen 5), dan (3) Recognition rather than recall (instrumen 6)".

Hasil penilaian yang diberikan masing-masing ahli yaitu dua orang ahli memberikan nilai 0.3 , dua orang ahli juga memberikan nilai 0.2 dan satu orang ahli memberikan nilai 0 dengan rerata nilai sebesar 0.2 . Sesuai ketentuan heuristic evaluation 0 menunjukkan bahwa aplikasi tidak ada masalah berkaitan dengan usability, 1 menunjukkan aplikasi memiliki masalah kosmetik, 2 menunjukkan aplikasi memiliki masalah minor, 3 menunjukkan aplikasi memiliki masalah major, dan 4 menunjukkan bahwa aplikasi harus dilakukan desain ulang. Berdasarkan hasil pengujian terhadapat mobile application travel guide yang mendapatkan nilai rerata 0.2 maka dapat dikatakan aplikasi tidak memiliki masalah usability. Dengan demikian mobile application travel guide dapat digunakan oleh wisatawan dalam mencari informasi yang berkaitan dengan parwisata di Provinsi Sumatra Selatan. 
Sedangkan hasil pengujian terhadap pengguna akhir menggunakan teknik SUS didapat hasil seperti yang diperlihatkan pada Tabel 6. Dalam proses pengujian ini melibatkan sebanyak sepuluh responden (Ependi et al., 2017).

\begin{tabular}{|c|c|c|c|c|c|c|c|c|c|c|}
\hline No & D1 & D? & D & & & & & & & \\
\hline & & & & & & & & & & \\
\hline 1 & 5 & 2 & 5 & 1 & 5 & 2 & 4 & 2 & 4 & 1 \\
\hline 2 & 5 & 1 & 4 & 2 & 5 & 2 & 5 & 1 & 4 & 2 \\
\hline 3 & 5 & 2 & 4 & 2 & 5 & 2 & 5 & 1 & 4 & 2 \\
\hline 4 & 4 & 3 & 4 & 2 & 5 & 2 & 5 & 1 & 4 & 3 \\
\hline 5 & 4 & 2 & 5 & 2 & 5 & 1 & 5 & 1 & 5 & 2 \\
\hline 6 & 4 & 2 & 4 & 1 & 5 & 1 & 4 & 1 & 4 & 3 \\
\hline 7 & 5 & 2 & 5 & 1 & 5 & 2 & 4 & 2 & 5 & 2 \\
\hline 8 & 4 & 2 & 4 & 1 & 5 & 2 & 4 & 2 & 4 & 2 \\
\hline 9 & 5 & 1 & 4 & 1 & 5 & 2 & 5 & 2 & 5 & 2 \\
\hline 10 & 4 & 1 & 4 & 2 & 5 & 2 & 4 & 2 & 4 & 2 \\
\hline
\end{tabular}

Dari hasil penilaian responden seperti yang diperlihatkan pada Tabel 6 maka selanjutnya lakukan perhitungan dengan ketentuan SUS. Ketentuan SUS yaitu (1) Instrumen ganjil skala jawaban responden dikurangi dengan 1. (2) Instrumen genap, 5 dikurangi skala jawaban responden. (3) Skala penilaian $0-4$ (4 adalah jawaban terbaik). (4) Menjumlahkan jawaban responden dan dikali 2.5. (5) Menentukan rerata jawaban untuk semua responden. Hasil perhitungan SUS pada kententuan 1, 2 dan 3 menghasilkan penilaian seperti yang diperlihatkan pada Tabel 7 .

Tabel 7. Hasil pengujian SUS setelah dilakukan perhitungan

\begin{tabular}{ccccccccccc}
\hline No & P1 & P2 & P3 & P4 & P5 & P6 & P7 & P8 & P9 & P10 \\
\hline $\mathbf{1}$ & 4 & 3 & 4 & 4 & 4 & 3 & 3 & 3 & 3 & 4 \\
$\mathbf{2}$ & 4 & 4 & 3 & 3 & 4 & 3 & 4 & 4 & 3 & 3 \\
$\mathbf{3}$ & 4 & 3 & 3 & 3 & 4 & 3 & 4 & 4 & 3 & 3 \\
$\mathbf{4}$ & 3 & 2 & 3 & 3 & 4 & 3 & 4 & 4 & 3 & 2 \\
$\mathbf{5}$ & 3 & 3 & 4 & 3 & 4 & 4 & 4 & 4 & 4 & 3 \\
$\mathbf{6}$ & 3 & 3 & 3 & 4 & 4 & 4 & 3 & 4 & 3 & 2 \\
$\mathbf{7}$ & 4 & 3 & 4 & 4 & 4 & 3 & 3 & 3 & 4 & 3 \\
$\mathbf{8}$ & 3 & 3 & 3 & 4 & 4 & 3 & 3 & 3 & 3 & 3 \\
$\mathbf{9}$ & 4 & 4 & 3 & 4 & 4 & 3 & 4 & 3 & 4 & 3 \\
$\mathbf{1 0}$ & 3 & 4 & 3 & 3 & 4 & 3 & 3 & 3 & 3 & 3 \\
$\sum$ & $\mathbf{3 5}$ & $\mathbf{3 2}$ & $\mathbf{3 3}$ & $\mathbf{3 5}$ & $\mathbf{4 0}$ & $\mathbf{3 2}$ & $\mathbf{3 5}$ & $\mathbf{3 5}$ & $\mathbf{3 3}$ & $\mathbf{2 9}$ \\
\hline
\end{tabular}

Dari hasil perhitungan SUS pada Tabel 7 maka proses selanjutnya melakukan proses perhitungan SUS utuk langkah 4 dan 5 yaitu menjumlahkan jawaban responden dan dikali 2.5. dan menentukan rerata jawaban. Untuk melakukan proses perhitungan SUS pada langkah ke empat (4) diperlukan jumlah dari masing-masing jawaban responden yang dapat dilihat pada Tabel 7. Untuk itu hasil akhir dari penilaian SUS pada Tabel 8.
Tabel 8. Penentuan nilai akhir SUS

\begin{tabular}{ccc}
\multicolumn{3}{c}{ Tabel 8. Penentuan nilai akhir SUS } \\
\hline Responden & Hasil Penilaian & Skor \\
\hline 1 & $35 \times 2.5$ & 87.5 \\
2 & $32 \times 2.5$ & 80 \\
3 & $33 \times 2.5$ & 82.5 \\
4 & $35 \times 2.5$ & 87.5 \\
5 & $40 \times 2.5$ & 100 \\
6 & $32 \times 2.5$ & 80 \\
7 & $35 \times 2.5$ & 87.5 \\
8 & $35 \times 2.5$ & 87.5 \\
9 & $33 \times 2.5$ & 82.5 \\
10 & $29 \times 2.5$ & 72.5 \\
& Rerata & $\mathbf{8 4 7 . 5} / \mathbf{1 0}=\mathbf{8 4 . 7 5}$ \\
\hline
\end{tabular}

Dari Tabel 8 dapat diketahui bahwa nilai rerata penialaian responden yaitu 84.75 . Jika dilihat dari kriteria SUS seperti yang diperlihatkan pada Gambar 7 maka mobile application yang dihasilkan dilihat dari sisi acceptability mendapatkan kategori acceptable. Dilihat dari grade scale mendapatkan kategori B. Sedangkan dilihat dari adjective rating mendapatkan kategori excelent. Dari hasil pengujian usability dengan teknik SUS maka dapat dikatakan bahwa pengguna menerima mobile application yang dihasilkan.

\section{KESIMPULAN}

Pariwisata menjadi bagian penting bagi sebuah negara dalam menggerakan perekonomian. Untuk mendorong pariwisata teknologi menjadi salah satu tulang punggung terutama teknologi mobile melalui aplikasi sebagai langkah menciptakan smart tourism. Untuk itu telah dihasilkan sebuah mobile application yang memiliki kategori informasi sport, transportation, hotel, store, restaurant, handicraft, tourism destination, gas station, hospital, police station, government office, and education yang ada di Provinsi Sumatra Selatan sebagai media penyedia informasi berkaitan pariwisata. Proses pengembangan mobile application dilakukan mengacu pada arsitektur aplikasi yang dapat digunakan sebagai referensi yang pengembangan mobile application pariwisata. Selain itu juga aplikasi telah siap untuk digunakan yang dibuktikan dari hasil pengujian dengan instrumen heuristic evalution yang mendapatakan nilai rerata 0.2 yang berarti mobile application tidak memiliki masalah usability. Sedangkan pengujian yang dilihat dari sisi pengguna menggunakan system usability scale mendapatkan nilai rerata 84.75 yang berarti bahwa pengguna dapat menerima dan menggunakan mobile application yang dihasilkan. Mobile application yang dihasilkan memiliki keterbatasan atau kekurangan diantanya yaitu: (1) tidak dapat diakses atau di-install untuk perangkat mobile berbasis IOS. Windows dan Amazone. (2) fitur history perjalanan untuk masing-masing travelers. Untuk itu saran bagi 
peneliti selanjutnya dapat melakukan penambahan fitur dengan melakukan analisi kebutuhan, serta pengembangan mobile application untuk perangkat mobile berbasis IOS. Windows dan Amazone.

\section{DAFTAR PUSTAKA}

ABDALHAMID, S. \& MISHRA, A. 2017. Adopting of Agile methods in Software Development Organizations: Systematic Mapping. TEM JOURNAL-TECHNOLOGY EDUCATION MANAGEMENT INFORMATICS, 6, 817-825.

ABDELlATIF, A. J., MCCOLlUM, B. \& MCMULLAN, P. Serious games: Quality characteristics evaluation framework and case study. Integrated STEM Education Conference (ISEC), 2018 IEEE, 2018. IEEE, 112-119.

ALQUDAH, M. \& RAZALI, R. 2016. A review of scaling agile methods in large software development. International Journal on Advanced Science, Engineering and Information Technology, 6, 828-837.

ANTOUN, C. 2015. Who Are the Internet Users, Mobile Internet Users, and Mobile-Mostly Internet Users?: Demographic Differences across Internet-Use Subgroups in the US. Mobile Research Methods, 99.

APJII 2018. Indonesia Internet Service Provider Association: Penetrasi dan Perilaku Pengguna Internet Indonesia. In: 2017, S. (ed.). Jakarta, .

BANGOR, A., KORTUM, P. \& MILLER, J. 2009. Determining what individual SUS scores mean: Adding an adjective rating scale. Journal of usability studies, 4, 114-123.

CHATZIGEORGIOU, C. \& SIMELI, I. 2017. Perception of service quality in agrotourism accommodations: Impact on guest loyalty and re-visit intentions. Journal of Tourism, Heritage \& Services Marketing, 3, 33-41.

DA CUNHA, T. F. V., DANTAS, V. L. \& ANDRADE, R. M. SLeSS: A Scrum and Lean Six Sigma integration approach for the development of sofware customization for mobile phones. 2011 25th Brazilian Symposium on Software Engineering, 2011. IEEE, 283-292.

DESURVIRE, H., CAPLAN, M. \& TOTH, J. A. Using heuristics to evaluate the playability of games. CHI'04 extended abstracts on Human factors in computing systems, 2004. ACM, 1509-1512.

EPENDI, U. 2017a. Geographic Information System Produksi Energi dan Pertambangan Kabupaten Musi Banyuasin. Jurnal Teknologi dan Sistem Informasi, 3, 360369.
EPENDI, U. 2017b. Heuristic Evaluation for Mobile Application (Studi Kasus: Aplikasi Depo Auto 2000 Tanjung Api Api Palembang). Simetris: Jurnal Teknik Mesin, Elektro dan Ilmu Komputer, 8, 563-570.

EPENDI, U. 2018. Pemodelan Sistem Informasi Monitoring Inventory Sekretariat Daerah Kabupaten Musi Banyuasin. KLIKKUMPULAN JURNAL ILMU KOMPUTER, 5, 49-60.

EPENDI, U., KURNIAWAN, T. B. \& PANJAITAN, F. 2019. SYSTEM USABILITY SCALE VS HEURISTIC EVALUATION: A REVIEW. Simetris: Jurnal Teknik Mesin, Elektro dan Ilmu Komputer, 10, 65-74.

EPENDI, U., PANJAITAN, F. \& HUTRIANTO, H. 2017. System Usability Scale Antarmuka Palembang Guide Sebagai Media Pendukung Asian Games XVIII. Journal of Information Systems Engineering and Business Intelligence, 3, 80-86.

FERDIANA, R., SANTOSO, P. I., NUGROHO, L. E. \& ASHARI, A. 2011. User Story Software Estimation: A Simplification Of Software Estimation Model With Distributed Extreme Programming Estimation Technique. JUTI: Jurnal Ilmiah Teknologi Informasi, 9, 41-48.

FLORA, H. K. \& CHANDE, S. V. 2013. A review and analysis on mobile application development processes using agile methodologies. International Journal of Research in Computer Science, 3, 8-18.

IBRAHIM, N. 2012. An Overview of Agile Software Development Methodology and Its Relevance to Software Engineering. Jurnal Sistem Informasi, 2.

INDONESIA, K. P. R. 2016. Peraturan Menteri Pariwisata Republik Indonesia Nomor 16 Tahun 2016 Tentang Statuta Politeknik Pariwisata Palembang. In: INDONESIA, K. P. R. (ed.). Jakarta: Kementrian Hukum dan Hak Asasi Manusia Republik Indonesia.

IVKOV-DŽIGURSKI, A., KOVAČEVIĆ, T. \& ZAKIĆ, L. 2008. Souvenirs as a part of cultural heritage of population in function of tourist product. Glasnik srpskog geografskog drustva, 88, 59-69.

JEONG, Y.-J., LEE, J.-H. \& SHIN, G.-S. Development process of mobile application SW based on agile methodology. Advanced Communication Technology, 2008. ICACT 2008. 10th International Conference on, 2008. IEEE, 362-366. 
LEWIS, J. R. 2014. Usability: lessons learned... and yet to be learned. International Journal of Human-Computer Interaction, 30, 663-684.

MAHMUD, D. M. \& ABDULLAH, N. A. S. Reviews on agile methods in mobile application development process. Software Engineering Conference (MySEC), 2015. 161-165.

NIELSEN, J. Finding usability problems through heuristic evaluation. Proceedings of the SIGCHI conference on Human factors in computing systems, 1992. ACM, 373-380.

NIELSEN, J. Usability inspection methods. Conference companion on Human factors in computing systems, 1994. ACM, 413414.

NIELSEN, J. 1995. How to Conduct a Heuristic Evaluation [Online]. United States: Evidence-Based User Experience Research, Training, and Consulting. Available: https://www.nngroup.com/articles/how-toconduct-a-heuristic-evaluation/ [Accessed June 8 2018].

PRESSMAN, R. 2009. Software Engineering A Practitioner's Approach 7th Ed-Roger S. Pressman. Software Engineering A Practitioner's Approach 7th Ed-Roger S. Pressman (p. 0).

PUDJOATMODJO, B. \& WIJAYA, R. 2016. Tes Kegunaan (Usabilty Testing) Pada Aplikasi Kepegawaian Dengan Menggunakan System Usabilty Scale (Studi Kasus: Dinas Pertanian Kabupaten Bandung). SEMNASTEKNOMEDIA ONLINE, 4, 2-937.

PUTRA, D. S. 2017. Sistem Informasi Geografis Tempat Wisata Edukasi Di DKI Jakarta Berbasis Android. Jurnal Integrasi, 9, 143148.

RAHIMIAN, V. \& RAMSIN, R. Designing an agile methodology for mobile software development: A hybrid method engineering approach. Research Challenges in Information Science, 2008. RCIS 2008. Second International Conference on, 2008. IEEE, 337-342.

RI, K. 2018. Jumlah kunjungan wisman ke Indonesia Desember 2017 mencapai 1,15 juta kunjungan [Online]. Jakarta: Kemenpar Republik Indonesia. Available: https://is.gd/tNeH2p [Accessed 28 2018].

SILVA, P. A., HOLDEN, K. \& JORDAN, P. Towards a list of heuristics to evaluate smartphone apps targeted at older adults: a study with apps that aim at promoting health and well-being. System Sciences (HICSS), 2015 48th Hawaii International Conference on, 2015. IEEE, 3237-3246.
TULLIS, T. S. \& STETSON, J. N. A comparison of questionnaires for assessing website usability. Usability professional association conference, 2004. Minneapolis, USA.

TUMIMOMOR, M., JANDO, E. \& MEOLBATAK, E. 2013. Sistem Informasi Geografis Pariwisata Kota Kupang. Jurnal Nasional Pendidikan Teknik Informatika, 2, 142-152.

VINANDARI, N., HAFIZD, K. A. \& NOOR, M. 2019. Sistem Informasi Geografis Wisata Religi Berbasis Web Mobile. Jurnal Sains dan Informatika $41-49 \% \mathrm{~V} 5$.

YUNIS, R. \& SURENDRO, K. Perancangan model enterprise architecture dengan TOGAF architecture development method. Seminar Nasional Aplikasi Teknologi Informasi (SNATI), 2009. 
Halaman ini sengaja dikosongkan 